\title{
Defining Human Factor and Ergonomic and its related issues in Malaysia Pineapple Plantations
}

\author{
Nur Fazrina Mohamad Salleh ${ }^{1}$ and Ezrin Hani Sukadarin ${ }^{1}$ \\ ${ }^{1}$ Occupational Safety and Health Program, Faculty of Engineering Technology, Universiti Malaysia Pahang, 26300 Gambang, \\ Pahang, Malaysia
}

\begin{abstract}
Human factor and ergonomic has been a standardized as synonymous for a long time and has great potential to contribute in designing all kinds of systems with people. However, some opinions draw precisely distinctions among these terms. Numerous studies have been conducted in their attempt to understand the concept of human factor and ergonomic. The meaning of each term must be clearly understood before using them in any research to understand how human beings interact with surroundings. So, this paper seeks to review the definition of human factor and ergonomic. English articles and books dated as far 1970 were compiled from Taylor and Francis Online, Google Scholar and Science Direct. The keywords used in the selection of the articles are human factors, human factors engineering, ergonomics, industrial ergonomics, reviews, definition, difference and risk factors. A risk model related to each term is also provided to have more understanding towards it. Based on the finding of the literature review of human factor and ergonomic issue in pineapple plantation were explore and are categorized accordingly.
\end{abstract}

\section{Introduction}

Pineapple or Ananas Cosmosus is a type of plant in tropical category originated from East area of South Africa. It was commercially introduced in Malaya in the $16^{\text {th }}$ century by the Portuguese. Pineapple plant began to be cultivated in Malaysia at Johor and Selangor area as cash crop in year 1921, along with rubber crop development. Pineapple plantation was then continued to expand in peat soil in Johor [1]. Pineapple plantation that falls under Malaysian Pineapple Industry Board (MPIB), recorded pineapple exports valued at RM 161 million in year 2015 and targets to increase to RM 254 million by year 2020. The plan to increase the country's pineapple production is to meet market demand and high-value agricultural development.

Agricultural sector is one of the primary sources of income in Malaysia especially among the community in the rural areas [2]. Labor works in agricultural industry has also increased from approximately 1.2 million to 1.4 million before year 2010 [3]. Escalation of work force and demand concurrently has increased the risk of occupational related accidents and diseases in agricultural sectors. In 2012, International Labor Organization (ILO) also highlighted that agricultural sector is one of the most hazardous types of work that lead to health issues worldwide. Same trend is observed in the Malaysian agricultural industry where by agriculture sectors are among highest sectors that reported occupational accident and diseases to Department of Occupational Safety and Health, Malaysia [4] .

Occupational related accidents and diseases that happen in agricultural sector especially in pineapple plantations normally are due to human related issue. Manual handling, fatigue due to overload, long duration of exposure sun light, job dissatisfaction, prolonged in an awkward posture of handling work, might be the factors that contribute to the aforementioned issues. Those factors simply used to be addressed as Human Factors and Ergonomics by many researchers. Although the used term is widely accepted, well understanding between those two terms would be beneficial for researchers in conducting more impactful research in this field. Due to that, this paper is about to (1) explore the definition or Human Factors and Ergonomic from published articles, (2) based on the gathered definition, this paper will discuss one published model that represent the factors for the two terms separately, (3) Human Factors and Ergonomics issue that arise in pineapple plantation activities are gathered and then are grouped into Human Factors risk and Ergonomics Risk.

Corresponding author: ezrin@ump.edu.my 


\section{Methodology}

To identify the definition of human factors and ergonomic, english articles and books dated as far 1970 were compiled from Taylor and Francis Online, Google Scholar and Science Direct. The keywords used in the selection of the articles are human factors, human factors engineering, ergonomics, industrial ergonomics, reviews, definition, difference and risk factors. PEAR Model (People, Environment, Action, Resources) [5] for human factors and a model by Carayon et al in 1999 [6] for ergonomics are also discussed because of those models represent each term very closely so that the understanding of human factors and ergonomics is obtained appropriately. After that, human factor and ergonomic issue in pineapple plantation, are identified and then classified into (1) human factor and (2) ergonomic.

\section{Results and Discussion}

\subsection{Human Factors and Ergonomics in a Glance}

Human factors and ergonomic is "the scientific discipline concerned on the perceptive of interactions among humans and other elements of a system, in order to enhance human well-being and overall system performance [5]. The importance of human factors and ergonomics was highlighted by author Carayon [6] as it is an oriented system, design driven to improve performance and well being of population.

The combination of human factors and ergonomic is now well accepted as can be seen, the term is started to be used over the decades. Human Factor and Ergonomic Organization from United Kingdom has been recognized as the oldest professional body since 1946. It is also called "The Chartered Institute of Ergonomics and Human Factors". The Human Factors and Ergonomics Society (HFES) were also founded in 1957 and were the main professional organization in the United States [9]. The International Ergonomics Association (IEA) is the federation of ergonomics and human factors societies around the world entitled as international organization. The IEA mission is to elaborate and enhance ergonomics science and practices. It also has 42 Federated Societies from across the globe.

Many professional considered that the terms ergonomics and human factors are synonymous. Many articles show that the definitions of these two terms are also similar. A number of excellent reviews covering several different topic areas of relevance to human factors and ergonomics, as well as handbooks and textbooks, are published with some constancy. While IEA [10] combines ergonomic and human factor in its definition as "Ergonomic (or human factors is the scientific discipline concerned with the understanding of interactions among humans and other elements of a system. The Ergonomic (or human factors) professional applies theory, principles data and methods to design in order to optimize human well-being and overall system performance. Table 1 shows the publication which combine human factors and ergonomic into one term.

However, according to Cambridge Dictionary, ergonomics is defined as the scientific study of people and their working conditions, especially done in order to improve effectiveness. While human factors is the act of studying how people use systems or equipment in order to design, develop and create technology that is safer and more effective. Human Factor is the discipline that integrates human capabilities, limitations, requirements and expectations in the design of products, workplaces and work systems while Ergonomics is the science of studying people at work and of their working environment [11]. And, in addition, traditionally ergonomic involves the physical aspects of work, while human factor involve perception and cognition [9].

Table 1. Definition of Human Factor/ Ergonomic

\begin{tabular}{|c|c|}
\hline Ref & Definition \\
\hline $\begin{array}{l}\text { Brown and } \\
\text { Hendrick } \\
{[12]} \\
\end{array}$ & $\begin{array}{l}\text { "...the relations between man and his working } \\
\text { environment..." }\end{array}$ \\
\hline $\begin{array}{l}\text { Meister } \\
\text { [13] }\end{array}$ & $\begin{array}{l}\text { "...the purpose of ergonomics/human factors is } \\
\text { to describe, analyze measure, predict, and } \\
\text { control the real world of systems functioning } \\
\text { operationally..." }\end{array}$ \\
\hline Pelsma [14] & $\begin{array}{l}\text { "...The application of knowledge about human } \\
\text { characteristics and capabilities - physical, } \\
\text { psychological, and cognitive - to the design of } \\
\text { work system with the goal of improving well- } \\
\text { being and optimizing productivity..." }\end{array}$ \\
\hline $\begin{array}{c}\text { Rubinstein } \\
{[15]}\end{array}$ & $\begin{array}{l}\text { "....the study of how people and machines } \\
\text { interact..." }\end{array}$ \\
\hline $\begin{array}{l}\text { Thomas } \\
{[16]}\end{array}$ & $\begin{array}{l}\text { "...focus on the relationship between humans } \\
\text { and their work... to design systems and its } \\
\text { environment that is more condusive and } \\
\text { happier..." }\end{array}$ \\
\hline
\end{tabular}

\subsection{Human Factor}

A field of human factor was motivated by a search for efficient and error-free operations in United States of America (USA) military in the Second World War (WWII). With its origins derived from concerns about piloting aircraft, human factors was originally much more focused on elements of cognition [17]. There are all 10 disciplines of human factor which is shown in Figure 1 [19]. It has long been recognized as a discipline of knowledge for improving people's health, safety, and comfort and both human and system productivity [20]. It involves a study on how humans behave physically and psychologically in relation to particular environments, products, or services. Literature finding also shows that human factor is originated from research in experimental psychology, which the focus was on human performance and systems design [18]. Table 2 shows the definitions of human factor and its references. 


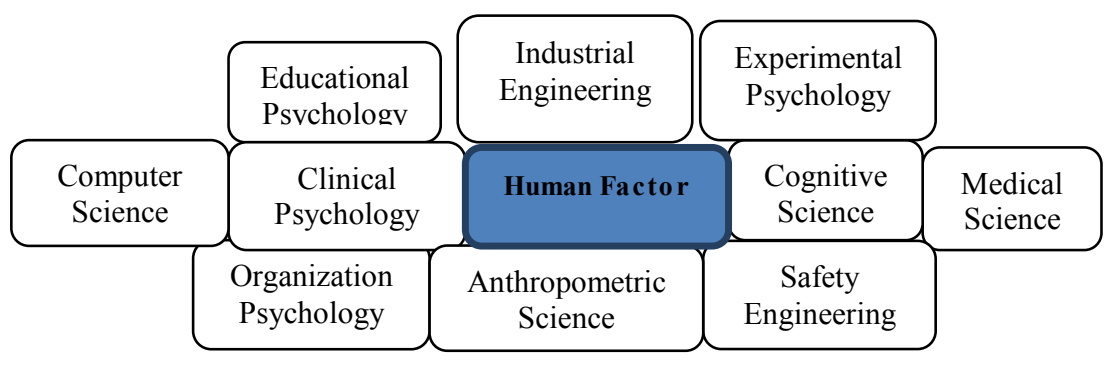

Fig. 1. Human Factor Disciplines

Table 2. The definition of human factors and its references

\begin{tabular}{|c|l|}
\hline Ref & \multicolumn{1}{|c|}{ Definitions } \\
\hline Bennet, Degan \& Spiegel[21] & $\begin{array}{l}\text { "...To recognize and understanding of man's characteristics, needs, abilities, and limitations when } \\
\text { the procedures and products of technology are being designed..." } \\
\text { "...human abilities, human limitations and other human characteristics that are relevant to design..." }\end{array}$ \\
\hline Chapanis [18] & $\begin{array}{l}\text { "...Concern on the characteristics of human beings. The term embraces all biomedical and } \\
\text { psychosocial considerations..." }\end{array}$ \\
\hline Dhillon [22] & $\begin{array}{l}\text { "...Human relationship with machines and equipment, with procedures and with the } \\
\text { environment..." }\end{array}$ \\
\hline Hawkins [23] & $\begin{array}{l}\text { "... b branch of psychology concerned with the design of environments and equipment that promote } \\
\text { optimum use of human capabilities and optimum efficiency and comfort..." }\end{array}$ \\
\hline Goldenson[24] & "...Optimization the linkage between technology and population..." \\
\hline
\end{tabular}

\subsubsection{A Model related to Human Factor}

For better understanding towards human factor term, a model used in describing human factor is discussed. PEAR model has been used as a memory jogger to characterize human factors [5]. PEAR was developed by Dr Michael Maddox and Dr Bill Johnson as a simple way for aviation maintenance personnel to classify human factors that relate to tasks and conditions within the maintenance environment [26]. Human factor is usually associated with the term 'Human Error'. Nearly most accidents and operating upsets involve some kind of human error. For example, over $70 \%$ of air-crashes are the result of human error rather than technical failure [26] .In air crashes, errors happen mostly involve failure to comply procedures, taking a short cut or making an (incorrect) assumption about the validity of an instrument reading. Other than that, error may occur during the response phase of an incident [14]. All of these are the examples of human related issues. This issue can be managed if PEAR model as the human factors programs is integrated in the system. There are four important considerations for human factors programs which is people who do the job, their working environment, action that they performed and resources to complete their task (refer Figure 2).

\subsubsection{People}

Focus on a person who execute the work and address the physical, psychological, physiological and psychosocial factors. This also including their mental state, cognitive capacity, physical capabilities and situations that may affect their interaction with others.

\subsubsection{Environment}

There are two types of working environment, physical workplace (eg: ramp or workshop) or organization environment that exists within the company. The physical environment includes ranges of temperature, humidity and workplace design. Oganizational environment are typically related to cooperation, communication and the culture of the company.

\subsubsection{Action}

Job Task Analysis (JTA) is one of the method in human factors approach to identify the knowledge, skills, and attitudes neded to perform each task in a given job. The JTA assist to identify what instructions, tools, and other resources are necessary.

\subsubsection{Resources}

The component of the people, environment, and actions dictate the resources. Many resources are tangible, such as tools, test equipment, computers and technical manuals. However, other resources are less tangible. The examples are the number and qualifications of staff to complete a job, the amount of time allocated, and the level of communication. 


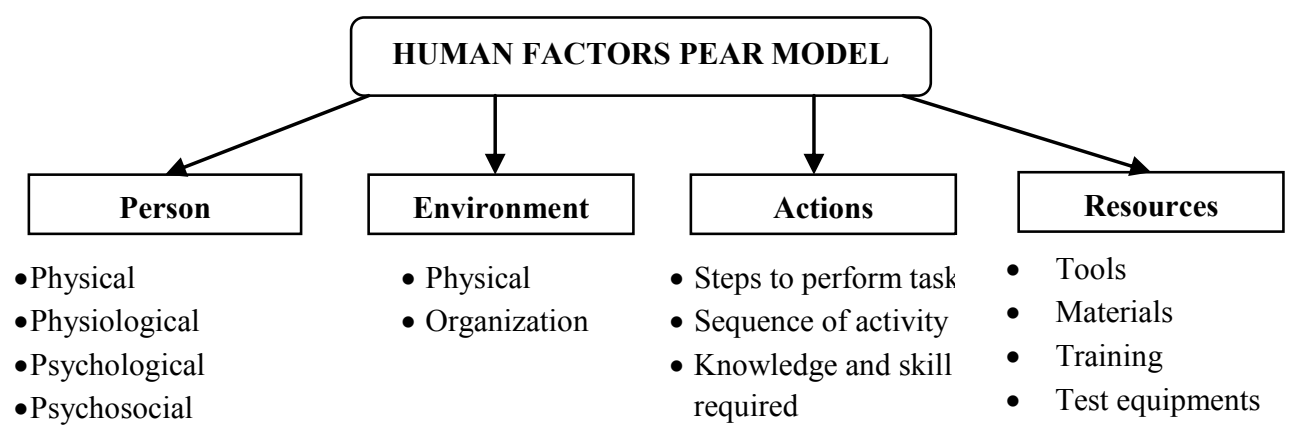

Fig. 2. Johnson and Maddox (2007) PEAR Model

\subsection{Ergonomic}

The word ergonomic is derived from the Greek words ergo (work) and nomos (laws). It was used for the first time by Wojciech Jastrzebowski in a Polish newspaper in 1857 [27]. Wojciech Jastrzebowski had suggested the term 'ergonomics' to represent the science of human work [29]. The name 'ergonomic' is retained in the title of many major scientific and professional organizations of Europe. Indeed, the name ergonomic is incorporated in many research societies worldwide, including the overall global organization, the International Ergonomics Association (IEA) [17].

In August 2000, the International Ergonomics Association Executive Council adopted the following definition "Ergonomic (or human factors) is the scientific discipline concerned with the understanding of interactions among humans and other elements of a system, and the profession that applies theory, principles, data and methods to design in order to advance human well-being and overall system performance [9]. Table 2 shows the ergonomic fragment and its explanation endorsed by IEA.

Table 2.Ergonomic fragment and its coverage

\begin{tabular}{|c|c|l|}
\hline Ref & Fgt & Coverage \\
\hline $\begin{array}{c}\text { Kroemer } \\
{[30]}\end{array}$ & $\begin{array}{c}\text { Physical } \\
\text { Ergonomic }\end{array}$ & $\begin{array}{l}\text { Anthropometrical, biomechanical, } \\
\text { and physiological information to } \\
\text { design physical environments }\end{array}$ \\
\hline $\begin{array}{c}\text { Harris } \\
{[31]}\end{array}$ & $\begin{array}{c}\text { Cognitive } \\
\text { Ergonomic }\end{array}$ & $\begin{array}{l}\text { Scientific understanding of } \\
\text { attention, perception, memory, } \\
\text { mental models, expertise, and } \\
\text { mental workload in designing } \\
\text { tools and systems }\end{array}$ \\
\hline $\begin{array}{c}\text { Chapanis } \\
{[18]}\end{array}$ & $\begin{array}{c}\text { Organizatio- } \\
\text { nal } \\
\text { Ergonomic }\end{array}$ & $\begin{array}{l}\text { Optimization of socio-technical } \\
\text { work systems including their } \\
\text { policies, structures and } \\
\text { organizational processes. }\end{array}$ \\
\hline
\end{tabular}

Currently, ergonomic practitioners collaborate directly with professionals in industrial engineering, systems safety, occupational medicine and industrial hygiene to reduce or prevent damage and injury on the job. The earlier historical of ergonomic spread largely within the countries that have emphasized on the importance of safe working conditions. Therefore, it is no surprise that ergonomic has initially been considered to be of European origin as in Europe, the focus of ergonomic is to be found in industry and it has been related to an interest in improving worker performance and satisfaction [32]. Table 3 shows the definition of ergonomic as be extracted from published work.

Table 3. Definition of Ergonomics and Its References

\begin{tabular}{|c|l|}
\hline Ref & Definition of Ergonomics \\
\hline NIOSH [33] & $\begin{array}{l}\text { Science of fitting workplace conditions } \\
\text { and job demands to the capabilities of the } \\
\text { working population (1) Effective and } \\
\text { successful "fits" assure high productivity } \\
\text { (2) Avoidance of illness and injury risks } \\
\text { (3) Increased satisfaction among the } \\
\text { workforce }\end{array}$ \\
\hline ILO [34] & $\begin{array}{l}\text { Ergonomics is the systematic study of } \\
\text { people at work with the objective of } \\
\text { improving the work situation, the working } \\
\text { conditions and the task performed }\end{array}$ \\
\hline OSHA US [35] & $\begin{array}{l}\text { Study of work. It is the science of } \\
\text { designing the job to fit the workers, rather } \\
\text { than physically forcing the worker's body } \\
\text { to fit the job }\end{array}$ \\
\hline HSE [36] & $\begin{array}{l}\text { Science concerned the "fit" between } \\
\text { people and their work. If put people first, } \\
\text { taking account of their capabilities and } \\
\text { limitation }\end{array}$ \\
\hline Humantech [37] & $\begin{array}{l}\text { Ergonomics is an approach or solution to } \\
\text { deal with a number of problems-among } \\
\text { them are work-related musculoskeletal } \\
\text { disorders }\end{array}$ \\
\hline
\end{tabular}

\subsubsection{A Model related to ergonomic}

To have better understanding of ergonomic term and its related factor, Job Stress Model by Carayon et al [6] that showing the factors for Work Related Musculoskeletal Disorders (WMSDs) is presented. This model illustrates job stress mechanisms; the work system (e.g. work organization, job design, work environment and technology) had a direct impact on short-term emotional, physiological and behavioural responses. Physical and psychological exposures could give impact to the development of WMSDs and individual factors might 
moderate the relationships between exposures and outcomes $[38,6]$. From this model, it is also showing that one of the factors which lead to WMSDs is biomechanical factors. In biomechanical studies, the underlying conceptual model signify that WMSDs are the result of tissue damage and/or pain produced when a worker is exposed to physically demanding work [40]. It is often used in ergonomics for understanding and controlling the risk of WMSDs. Psychosocial profile includes psychosocial risks which can derived from the organisation and design of work are associated with chronic health conditions in workers including depression, anxiety and musculoskeletal disorder $[41,42]$. Morphological characteristic and generic traits also believed may influence the cause and effect of individual musculoskeletal system which towards the end it will cause strain to human body. However, based on Carayon et al [6], individual biochemical and physiological together with individual body structure may affect individual pain threshold limit due to perception and knowledge that they keep in their mind.

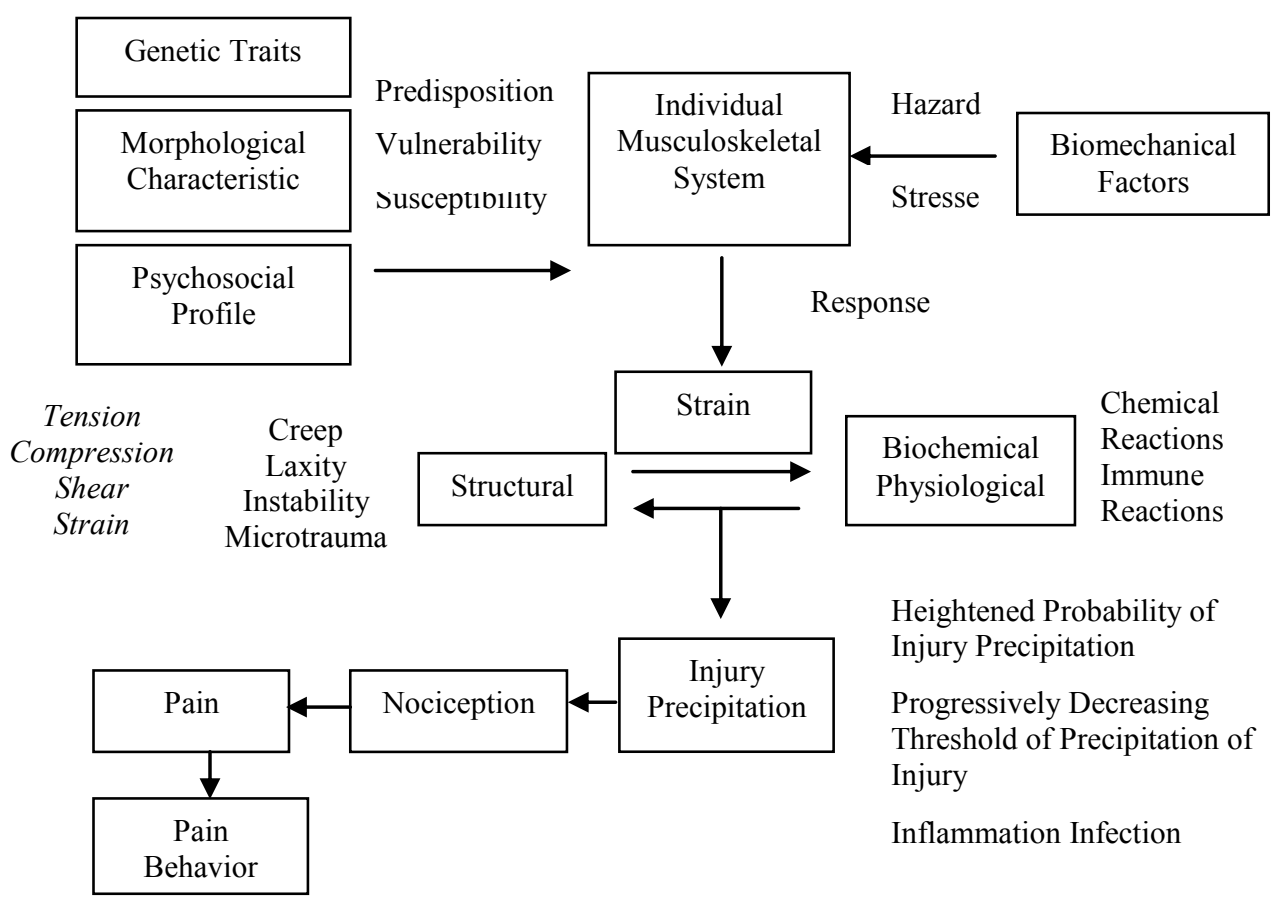

Fig. 3. Carayon et al. (1999) model of job stress

\subsection{Human Factor and Ergonomics in Malaysia's Pineapple Plantations}

Human factors and ergonomics related terms are considered equivalent by many, although some opinions draw precisely distinctions among these terms. The focus of ergonomic implementation should removes barriers to quality, productivity and most importantly to keep safe human performance by fitting products, tasks, and environments to people [45]. On the other hand, human factor should focus on applying knowledge in designing systems that work, accommodating the limits of human performance and exploiting the advantages of the human operator in the designated process [44]. Salvendy [45] also stated that the word ergonomic implies the study of man at work while word human factor imply the study of man in relation to equipment and environment. From all these opinion, it can be concluded that ergonomic is emphasis on how work affects people while the human factor is often on designs that reduce the potential for human error [43].
After the definition of both (human factor and ergonomic) have revealed, it is easy to capture human factor issue as well as ergonomic issue in pineapple plantation activities. Basically, pineapple plants grow low on the ground. In general, work activities in pineapple plantation requires workers to stoop in a prolonged times. Repetitive task that put a lot of strain on the body, involving the lower limbs such as constant bending over to plant seeds, weed and harvest pineapples are norms [2] . In a study conducted by Guo et al., [46] among 122 pineapple workers in the Southern Taiwan showing that the work activities involved with high prevalence of heavy manual work. It also in line with other studies that focus of manual work in other plantation [47, 48]. Figure 4 shows four main steps in planting pineapples whereby it involves preparing the land, planting, maintaining the crops and lastly, harvesting the pineapple (Figure 4). 


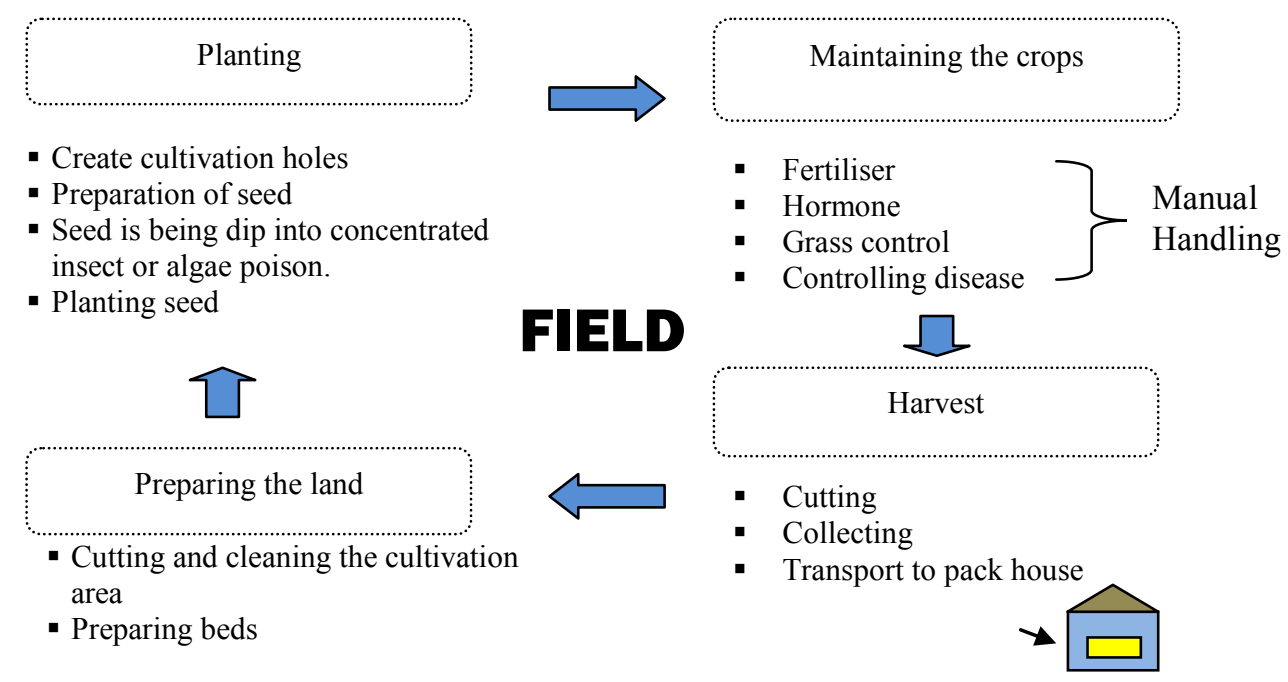

Fig. 4. Main Processes (Steps) in Pineapple Plantation

Table 4. Pineapple plantation activities and the possible issues facing by workers

\begin{tabular}{|c|c|c|c|}
\hline Activity & Ergonomic & Human Factor & Safety \\
\hline Preparing the land & $\begin{array}{l}\text { Back pain from prolonged and awkward } \\
\text { bending }\end{array}$ & \multirow{4}{*}{$\begin{array}{l}\text { Poor knowledge to working } \\
\text { safely } \\
\text { - } \quad \text { Low job satisfaction due to } \\
\text { environment condition } \\
\text { - } \quad \text { Low income but physical } \\
\text { demanding job } \\
\text { - } \quad \begin{array}{l}\text { Inadquate facilities such as } \\
\text { appropriate place for breaks }\end{array}\end{array}$} & $\begin{array}{l}\text { Sharp objects (hoe, } \\
\text { cleaver) can cause minor } \\
\text { or major cut }\end{array}$ \\
\hline Planting & $\begin{array}{l}\text { Awkward squatting position can cause } \\
\text { numbness on knees }\end{array}$ & & Exposure to heat stress \\
\hline Maintaining Crops & $\begin{array}{l}\text { Prolonged standing that can cause } \\
\text { muscle strain on back and waist }\end{array}$ & & Chemicals exposure \\
\hline Harvest & $\begin{array}{l}\text { Awkward bending and overexertion of } \\
\text { waist and arm and heavy lifting }\end{array}$ & & Manual handling \\
\hline
\end{tabular}

Ergonomic issues in pineapple plantation such as activities that require workers to bend awkwardly with the use of force most of the time to fulfil the work task are unavoidable. Meanwhile, human factor issue such as satisfaction of workers towards their salary, workers acceptance on the overall of the work system including, human to human, human to tools or machineries, and the relation of human to the surrounding are the things that also need to be taken seriously. Table 4 shows the problems associated with pineapple plantation activities that categorized into human factor, ergonomic and others issue.

\section{Conclusions}

In Malaysia pineapple plantation, some issues involving Human Factor and Ergonomics is revealed. Ergonomic issue such as constant and prolonged awkward postures is directly associated with Work-related Musculoskeletal Disorders (WMSDs) as this poor postures are one of the common risk factors of developing musculoskeletal problems among workers such as low back pain and knee pain. Human Factor issues such as inadequate facilities and low job satisfaction shows how humans behave physically and psychologically in relation to particular environments. The oucomes from this Human Factor issue is possibly pineapple plantation workers are not willing and happy to do their job, several areas of their work are affected, productivity loss and high employess turnover rates.

Ergonomic approach is aimed to optimise human interactions with systems, on how to make human activities more efficient, safe, comfortable and satisfying. While, human factor is the discipline to do with the design of systems in order to reduce human error and minimize ergonomics problems. So, to attain both goals effectively, the field needs a clear, concise, unambiguous and usable term to describe experts' efforts. As for now, it is clearly can be seen that the term ergonomics will take that role, along with adjectives of physical and cognitive. Regardless of the terms and labels that are used, the aim is always to optimize human efficiency, effectiveness, health, safety, and well-being, 
within the context of overall system performance operability, reliability, and maintainability. Ergonomic and Human Factor can made environments to be safer and more usable, efficient, and enjoyable for people to interact with. However, in pineapple plantation, it is good to really understand the differences between these two terms, so that planning to inculcate safe and healthy culture is easy to be achieved. Because, the human factor issue needs different approach to be tackled and ergonomic need different technique to be managed in the workplace setting.

This project is financially funded by the grant of Universiti Malaysia Pahang, Malaysia (Grant Number: RDU170308) (www.ump.edu.my).

\section{References}

[1] Malaysian Pineapple Industry Board, Retrieve from: http://www.mpib.gov.my/en/;jsessionid2 (2017)

[2] S.B.M. Tamrin \& Aumran. A comparison of the hazards, the risks, and the types of control in three selected agricultural industries. Occupational Safety and Health in Commodity Agriculture :Case Studies from Malaysian Agriculture Perspective, 1: 93-146 (2014)

[3] Department of Agriculture, Agriculture Statistic Handbook, Websites Retrieved from http://www.doa.gov.my (2008)

[4] Department of Occupational Safety and Health. Occupational Accidents Statistics by Sector Website Retrieve from http://www.dosh.gov.my/index.php/en/occupatio nal-accident-statistics/by-sector (2017)

[5] W. Johnson and M. Maddox, A PEAR Shaped Model For Better Human Factors Civ. Aviat. Train Mag., 3-4 (2007)

[6] P. Carayon, M. J. Smith, and M. C. Haims, Work Organization, Job Stress, and Work-Related Musculoskeletal Disorders. Hum. Factors J. Hum. Factors Ergon. Soc., 41, 644-663 (1999).

[7] M. Hassall, T. Xiao, P. Sanderson, and A. Neal, International Encyclopedia of the Social \& Behavioral Sciences, Second Edi Elsevier, 11 (2015)

[8] J. Dul, R. Bruder, P. Buckle, P. Carayon, P. Falzon, W. S. Marras, J. R. Wilson, and B. Van Der Doelen. A strategy for human factors / ergonomics: developing the discipline and profession, 1-27 (2012)

[9] P. G. Dempsey, M. S. Wogalter, and P. A. Hancock. Defining Ergonomics / Human Factors Taylor \& Francis Group (2006)

[10] International Ergonomic Association, Definition and Domains of ergonomics, http://www.iea.cc/whats/index.html (2017).

[11] I. Sutton, Chapter 8 - Human factors and ergonomics, 160-177 (2015)

[12] O. Brown, H. W. Hendrick, (Eds.), Human factors in organizational design and management - II. Amsterdam: North-Holland (1986)
[13] D. Meister , Behavioral analysis and measurement methods, New York: John Wiley \& Sons (1985)

[14] K. H. Pelsma, Ergonomics sourcebook: A guide to human factors information. Lawrence, KS: The Report Store (1987).

[15] R. Rubinstein, H. Hersh, The human factor: Designing computer systems for people. Bedford, MA: Digital Press (1984)

[16] J. C. Thomas, Organizing for human factors. In Y. Vassilou (Ed.), Human factors and interactive computer systems Norwood, NJ: Ablex Publishing, 29-46 (1984)

[17] P. A. Hancock, Human Factors/Ergonomics, 2nd ed. Elsevier Inc (2012)

[18] A. Chapanis, Ergonomics in product development: a personal view, $\mathbf{3 8}$ (1995)

[19] F. Wikipedia, Human factors, 5 1-13 (2008) Retrieved from https://www.faa.gov/regulations_policies/handbo oks_manuals/aircraft/media/AMT_Handbook_A ddendum_Human_Factors.pdf

[20] H. W. Hendrick, Good Ergonomics Is Good Economics, Proc. 40th Annu. Meet. Hum. Factors Ergon. Sciety, 1-15 (1996)

[21] E. Bennett, J. Degan, J. Spiegel, Human factors in a technological society. New York: McGrawHill, (1963)

[22] B.S. Dhillon, Human reliability with human factors, New York: Pergamon Press (1986)

[23] F. H. Hawkins, Human factors in flight, England: Gower Technical Press (1987).

[24] R. M. (Ed. ). Goldenson, Longman Dictionary of Psychology and Psychiatry, (1984)

[25] B. H. Kantowitz, R.D Sorkin, Human factors: Understanding people-system relationships. New York: John Wiley \& Sons (1983)

[26] J. Reasons, Human Factors: Resource guide for Engineers. Civil Aviation Safety Authority Australia (2001)

[27] P. A. Brennan, D. A. Mitchell, S. Holmes, S. Plint, and D. Parry, Good people who try their best can have problems: Recognition of human factors and how to minimise error, Br. J. Oral Maxillofac. Surg 54 3-7 (2016)

[28] W. Karwowski, International Encyclopedia of Ergonomics and Human Factors, 2nd edn.,1, Boca Raton, FL: CRC Press (2006)

[29] W. Jastrzebowski, An Outline of Ergonomics or the Science of Work Based on the Truths Drawn from the Science of Nature (reprinted by the Central Institute for Labour Protection, Warsaw, Poland) 29 (1857)

[30] K. H. E. Kroemer, E. Grandjean, Fitting the Task to the Human: A Textbook of Occupational Ergonomic, Taylor \& Francis, Bristol, PA. (2009)

[31] D. (Ed). Harris, Engineering Psychology and Cognitive Ergonomics: Understanding Human Cognition (2013)

[32] G. Salvendy, Handbook of human factors and 
ergonomics, 9, 3(1997)

[33] L.C. Alexander, C.G. Christopher, J.F. Lawrence, P.B. Bruce, D.M. James, Elements of Ergonomics Programs - A Primer Based on Workplace Evaluations of Musculoskeletal Disorders (1997)

[34] International Labour Office, 15, 93 (1998).

[35] OSHA US, Ergonomics: The Study of Work (2000)

[36] Health and Safety Executive, Ergonomics and human factors at work, 1-10 (2013)

[37] Humantech, Definition of Occupational Ergonomics, 1-4, Website Retrieve from https://www.humantech.com/wpcontent/uploads/ 2016/06/Definition-of-Occupational-

Ergonomics-Position-Paper.pdf (2016)

[38] Sauter, S.L. and Swanson, N.G, An ecological model of musculoskeletal disorders in office work. In Beyond biomechanics: Psychosocial Aspects of musculoskeletal disorders in office work, Bristol, PA: Taylor and Francis, 3-22 (1996)

[39] P. Carayon, M.J. Smith, M.C. Haims, Work organization, job stress, and work- related musculoskeletal disorders, Hum. Factors, 41, 644-663 (1999)

[40] M.S. Kerr, Workplace Psychosocial Factors and Musculoskeletal Disorders: A Discussion Paper (1998)

[41] E.-M. Backé, A. Seidler, U. Latza, K. Rossnagel, B. Schumann, The role of psychosocial stress at work for the development of cardiovascular diseases: A systematic review, Int. Arch. Occup. Environ. Heal. 85 67-79 (2012)

[42] H. Sultan-Taïeb, C. Lejeune, A. Drummond, I. Niedhammer, Fractions of cardiovascular diseases, mental disorders, and musculoskeletal disorders attributable to job strain. Int. Arch. Occup. Environ. Health, 84, 911 - 925 (2011)

[43] N. Jaffar, A.H. Abdul-Tharim, I.F. MohdKamar, N.S. Lop, A literature review of ergonomics risk factors in construction industry,Procedia Eng., 20, 89-97 (2011)

[44] C.D. Wickens, Engineering psychology and human performance. Columbus: Charles Merrill Publishing (1984)

[45] G. Salvendy, Has ergonomics the same meaning in Europe and North America? In I.D. Brown, R. Goldsmith, M.A. Sinclair (Eds.), Ergonomics international London: Taylor \& Francis, 85, 9798 (1985)

[46] Y. Guo, B. Wang, C. Lee, J. Wang, Prevelance of dermatoses and skin sensitisation associated with use of pesticides in fruit farmers of southern Taiwan, Occup. Environ. Med., 53, 427-431 (1996)

[47] E. H. Sukadarin, B. M Deros, N. S. M. Syazwani, J. A. Ghani, A. R. Ismail and J. Zakaria, Back Pain and the Observed Factors among Oil Palm Workers, International Journal of Engineering Technology And Sciences (IJETS) 5 (1) (2016)
[48] E. H. Sukadarin, B. M Deros, N. S. M. Syazwani, J. A. Ghani, A. R. Ismail and J. Zakaria, A Preliminary Study of Postural Problems among Oil Palm Workers: Is OWAS method suitable to investigate those problems? International Journal of Engineering Technology And Sciences (IJETS) 5 (1) (2016) 